\title{
New Disease Reports \\ A trunk canker disease of Tectona grandis induced by Lasiodiplodia theobromae in Brazil
}

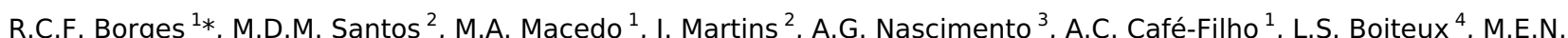
Fonseca ${ }^{4}$, C.A. Inácio ${ }^{5}$ and S.C.M. Mello ${ }^{2}$

${ }^{1}$ Departamento de Fitopatologia, Universidade de Brasília, 70910-900, Brasília-DF, Brazil; ${ }^{2}$ Embrapa Recursos Genéticos e Biotecnologia, CP 02372, 70770-900, Brasília-DF, Brazil; ${ }^{3}$ Floresteca, 78470-000, Rosário Oeste-Bauxi-MT, Brazil; ${ }^{4}$ Embrapa Hortaliças, CP 218, 70359-970 Brasília-DF, Brazil; ${ }^{5}$ Departamento de Entomologia e Fitopatologia, Universidade Federal Rural do Rio de Janeiro, 23890-000, Seropedica, RJ, Brazil

*E-mail: rafaelafal@hotmail.com

Received: 03 Mar 2015. Published: 31 May 2015. Keywords: teak, molecular diagnosis

Tectona grandis (teak) is currently expanding as a commercial timber crop in tropical Brazil. Teak trees displaying unusual canker lesions with abundant exudation of a viscous resin were observed in field inspections in Cáceres, Mato Grosso (MT) State, Brazil. Other symptoms observed were the presence of brownish vascular tissue discoloration, heartwood rot (Fig 1) and dieback. The incidence of affected trees ranged from 5 to $10 \%$ across all inspected commercial fields.

Affected vascular tissue segments were cultivated in water agar medium aiming to isolate the organism potentially associated with these symptoms. Agar plugs of fungal mycelia growing from the tissue were transferred to sterile petri dishes containing potato dextrose agar (PDA) to isolate pure cultures. All resulting cultures were similar, initially white, turning gradually grey on the upper side of the plate and black on the reverse side. The cultures displayed holoblastic, hyaline conidiogenous cells, subcylindrical to cylindrical to ampulliform ranging in size from 4-7 x 1-2 $\mu \mathrm{m}$. Immature conidia were hyaline, ovoid and unicellular that upon maturity became thick-walled, dark brown with one septum and conspicuous longitudinal striations. Mature conidia ranged in size from 23-29 x 13-15 $\mu \mathrm{m}$ (Fig. 2). According to these characteristics, the fungus was identified as Lasiodiplodia theobromae (Alves et al., 2008). In order to confirm the morphological identification, portions of the rDNA region were sequenced. The obtained sequences were deposited in the GenBank database. The resulting sequence of the ITS1-5.8S-ITS2 rDNA region, using ITS1-ITS4 primers (White et al., 1990) of the Brazilian isolate from teak (Accession No. KP642037), shared 100\% identity with the $L$ theobromae isolate from Jatropha curcas reported in Malaysia (HM466960.2). In addition, the targeted conserved portion of the translation factor 1- $\alpha$ (TEF-1 $\alpha$ ) gene (O'Donnell et al., 1998) of the Brazilian isolate (KP642038) shared 100\% identity with the sequence from one L. theobromae isolate CMW9971 from Schizolobium parahyba (KF886731).

Three elite teak clones were inoculated with two L. theobromae isolates (RB01 and RB05) in order to fulfil Koch's postulates. Pathogenicity assays were conducted under greenhouse conditions using an inoculation methodology essentially as described by Silveira et al. (2006). Inoculation was carried out on plants, 180 days after being transplanted, by placing 2 $\mathrm{mm}$ diameter mycelial plugs of the isolates grown on PDA for 14 days in artificially made wounds ( $2 \mathrm{~cm}$ diameter) in the vascular cambium tissue (5 $\mathrm{cm}$ above the crown region). For the control treatments, the vascula cambium was inoculated with PDA plugs free of fungal growth. All three elite clones displayed canker symptoms identical to those observed in natural infections in the commercial fields 90 days after inoculations (Fig. 3). The fungus was re-isolated from all inoculated plants, fulfilling Koch's postulates. Lasiodiplodia theobromae has been reported in a number of species in Brazil, such as Acacia sp., Eucalyptus sp., Hevea brasiliensis and Mangifera indica (Mendes et al., 1998). However, only one report of this fungus infecting teak was found, from India, in 2007 (Murali et al., 2007). Hence, to our knowledge, this is the first formal report of $L$. theobromae causing canker disease teak in Mato Grosso State, Brazil. This new disease represents a serious threat to the commercial industry, since the affected trees are unsuitable for timber purposes.

\section{References}

Alves A, Crous PW, Correia A, Phillips AJL, 2008. Morphological and molecular data reveal cryptic speciation in Lasiodiplodia theobromae. Fungal Diversity 28, 1-13.

Mendes MAS, Silva VL, Dianese, JC, Ferreira MASV, Santos CEN, Neto EG, Urben AF, Castro C, 1998. Fungos em Plantas no Brasil. Brasilia-DF, Brazil: Brazilian Corporation for Agricultural Research (Embrapa)-SPI/Embrapa-Cenargen.

Murali TS, Suryanarayanan TS, Venkatesan, G, 2007. Fungal endophyte communities in two tropical forests of southern India: diversity and host affiliation. Mycological Progress 6, 191-199.

http://dx.doi.org/10.1007/s11557-007-0540-2

O’Donnell K, Kistler HC, Cigelnik E, Ploetz, RC, 1998. Multiple evolutionary origins of the fungus causing Panama disease of banana: Concordant evidence from nuclear and mitochondrial gene genealogies. Proceedings of the National Academy of Sciences 95, 2044-2049.

Silveira SF, Harrington TC, Mussi-Dias V, Engelbrecht CJB, Alfenas AC, Silva CR, 2006. Annona squamosa, a new host of Ceratocystis fimbriata. Fitopatologia Brasileira 31, 394-397.

http://dx.doi.org/10.1590/S0100-41582006000400010

White TJ, Bruns T, Lee S, Taylor J, 1990. Amplification and direct sequencing of fungal ribosomal genes for phylogenetics. In: Innis MA, Gelfand DH, Shinsky J, White TJ, eds. PCR protocols. A guide to methods and applications. San Diego, CA, USA: Academic Press, 315-322.

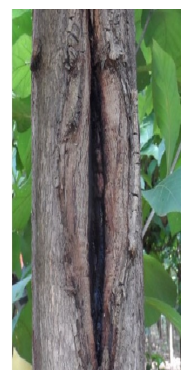

Figure 1

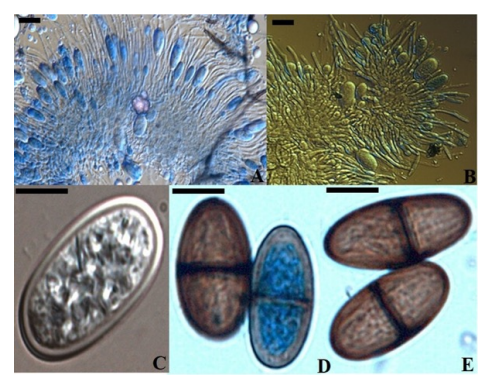

Figure 2
Figure 3

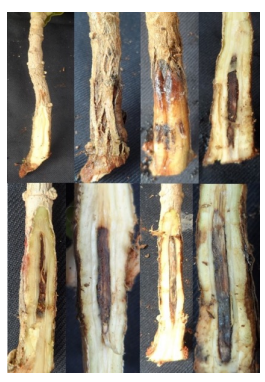

To cite this report: Borges RCF, Santos MDM, Macedo MA, Martins I, Nascimento AG, Café-Filho AC, Boiteux LS, Fonseca MEN, Inácio CA, Mello SCM, 2015. A trunk canker disease of Tectona grandis induced by Lasiodiplodia theobromae in Brazil. New Disease Reports $\mathbf{3 1}, 26$. http://dx.doi.org/10.5197/j.2044-0588.2015.031.026 (C) 2015 The Authors
This report was published on-line at www.ndrs.org.uk where high quality versions of the figures can be found. 